\title{
Andrzej Friszke, Adam Ciołkosz. Portret polskiego socjalisty, Wydawnictwo Krytyki Politycznej, Warszawa 2011, ss. 510
}

W ostatnim czasie na rynku wydawniczym nakładem Wydawnictwa Krytyki Politycznej ukazała się interesująca biografia naukowa poświęcona socjaliście Adamowi Ciołkoszowi. Najlepszą rekomendacją dla książki wydaje się osoba jej autora. Profesor Andrzej Friszke należy dziś do najwybitniejszych badaczy historii najnowszej specjalizujących się w historii II RP i PRL, ze szczególnym uwzględnieniem życia politycznego emigracji oraz historii opozycji politycznej w Polsce po 1944 r. Jest autorem wielu cenionych publikacji. Dość wspomnieć takie tytuły jego książek, jak: Zycie polityczne emigracji (1999), Polska. Losy państwa i narodu 1939-1989 (2003) oraz Anatomia buntu. Kuroń, Modzelewski i komandosi (2010). Ostatnia publikacja uznana została najlepszą książką historyczną 2011 r., a autor otrzymał nagrodę im. Kazimierza Moczarskiego.

Najnowsza publikacja A. Friszke pozwala odświeżyć pamięć o nieco zapomnianej dziś postaci wybitnego i aktywnego działacza Polskiej Partii Socjalistycznej Adama Ciołkosza. Bardziej zorientowani powinni kojarzyć Ciołkosza z jego licznymi publikacjami, w tym najbardziej znanym dwutomowym dziełem pt. Zarys dziejów socjalizmu (do powstania PPS) napisanym wspólnie z żoną Lidią.

Stworzenie portretu tytułowego bohatera to niewątpliwie główne założenie autora, choć nie jedyne. Życiorys Ciołkosza pomaga historykowi rozprawić się z pewnymi mitami i nadal funkcjonującymi stereotypowymi ujęciami historiograficznymi niekomunistycznej polskiej tradycji lewicowej. Nie przypadkiem zapewne na skrzydle okładki książki wyeksponowany został fragment z odautorskiego wstępu następującej treści:

W ostatnim dziesięcioleciu narasta we mnie sprzeciw wobec zapominania i fałszowania niekomunistycznej polskiej tradycji lewicowej. Niemal 
powszechne stało się niezrozumienie, czym była PPS, na czym polegała jej działalność, czym różni się socjalizm od komunizmu. Równolegle narasta popularność prawicowych ideologii i schematów myślenia, rehabilitacja totalistycznych nurtów prawicy, relatywizowania bezprawia, jakie dokonywało się w przedwojennej Polsce, lekceważenia pytań o demokrację, jej ograniczenia i pułapki. [...] Zrozumiałem, że poprzez ukazanie losów i wyborów Ciołkosza można powiedzieć coś istotnego, zwrócić uwagę na sprawy i dylematy, które zostały wyparte ze świadomości. I że ta publikacja może ułatwi bardziej racjonalny ogląd epoki, o której traktuje.

Podczas lektury książki można odnieść wrażenie, że dochodzi w niej do ideowej konfrontacji światopoglądu lewicowego, socjalistycznego, uosabianego przez PPS i głównego bohatera, z prawicowym, nacjonalistycznym, uosabianym przez endecję i niektóre środowiska sanacyjne. Autor, przy całej rzetelności, jaką winien zachować badacz historii, nie kryje swojej sympatii dla bohatera książki, jak i reprezentowanej przez niego opcji politycznej oraz ideowej. Pisze bowiem we wstępie: „Jako autor książki nie ukrywam, że podzielam wiele wyborów mojego bohatera, w tym sprzeciw wobec nacjonalizmu, który stanowił śmiertelną groźbę dla odbudowanej Rzeczypospolitej”.

Zamysł napisania biografii o Adamie Ciołkoszu profesor Friszke uzasadnia natomiast w sposób następujący:

Dlaczego bohaterem tej książki jest Adam Ciołkosz? Jego biografia jest przykładem awansu młodego człowieka ze średniego miasta prowincjonalnego, poprzez aktywność społeczną i polityczną, do elity politycznej partii. Stał się jednym z najbardziej znanych polityków swego pokolenia już w latach 30. Był posłem na Sejm, więźniem brzeskim, odsiedział wyrok więzienia, przewodził dużej organizacji partyjnej w Krakowskiem, należał do centralnych władz PPS. W czasie wojny był jednym z najbardziej znanych polityków na emigracji, uczestniczył w ważnych wydarzeniach, miał wyrobiony pogląd na wiele spraw, choć oczywiście nie zawsze był to pogląd słuszny. Po wojnie należał do najbardziej znanych przywódców emigracji politycznej, zarazem też był publicystą i historykiem. Właśnie w tym charakterze przemawiał z Londynu do kraju na falach Radia wolna Europa. 
Wypowiedź powyższa stanowi jakby kwintesencję niezwykle bogatego i aktywnego życia bohatera książki.

Bardzo rozbudowana faktografia to jedna z cech, którą należy zapisać na konto zalet publikacji, tym bardziej że jest ona podparta różnorodnymi źródłami. Świadczy to o rzetelnej i żmudnej kwerendzie przeprowadzonej przez autora. Okoliczności dotarcia do kluczowych dla pracy materiałów zostały przedstawione w części wstępnej. Natomiast w nocie bibliograficznej wskazane zostały najważniejsze zespoły akt.

Z pewnością dostęp do wielu istotnych źródeł nie byłby możliwy, jak sam autor zaznacza, bez pomocy żony bohatera książki - również działaczki PPS - Lidii Ciołkoszowej. To ona, już po śmierci męża, na początku lat 80. udostępniła autorowi prywatne zbiory jego dokumentów znajdujące się w ich londyńskim mieszkaniu. Archiwum Adama i Lidii Ciołkoszów okazało się kopalnią informacji na temat PPS, czasu wojny i okresu powojennego. Natomiast kontakt z Ciołkoszową pozwolił autorowi wzbogacić informacje zaczerpnięte $\mathrm{z}$ dokumentów o relacje uczestnika tamtych wydarzeń. Lidia Ciołkoszowa (zm. w czerwcu 2002 r.), jak wynika z relacji prof. Friszke, bardzo liczyła, że to właśnie on podejmie trud napisania biografii jej męża. Obecnie Archiwum Adama i Lidii Ciołkoszów znajduje się w Instytucie Polskim i Muzeum im. Gen. Sikorskiego w Londynie, gdzie autor znalazł także inne materiały cenne dla podjętego tematu. W pracy wykorzystano bowiem znajdujące się tam zbiory archiwalne dla badania dziejów emigracji powojennej, m.in. zespół Prezydium Rady Ministrów, Ministerstwa Spraw Wewnętrznych, Rady Narodowej oraz kolekcje Tomasza Arciszewskiego, czy Stanisława Kota. Autorowi udało się pozyskać kopie dokumentów pochodzących z zespołu akt Zygmunta Zaremby, które przechowywane są w Polskim Instytucie Naukowym w Nowym Yorku. Zagraniczna kwerenda uzupełniona została o kwerendę przeprowadzoną w archiwach i bibliotekach krajowych, m.in. w Archiwum Akt Nowych. Wielce przydatna przy rekonstrukcji poruszanych w książce faktów okazała się także prasa polityczna, przede wszystkim socjalistyczna.

Do pisania biografii prof. Friszke przystąpił w połowie lat 90., jednak inne zobowiązania badawcze spowodowały, że zdołał doprowadzić pracę do 1949 r. Pozostało zatem do opracowania 28 lat życia i aktywności Ciołkosza zmarłego 1 X 1978 r. Autor zdecydował się jednak opubli- 
kować pierwszą część opracowania, zapowiadając przygotowanie drugiego tomu biografii.

Życiorys Adama Ciołkosza opisany w 18 rozdziałach można podzielić na dwa etapy - aktywność w kraju i na emigracji. Opowieść o głównym bohaterze zaczyna się jak tradycyjna biografia osadzona w logicznym ciągu chronologicznym, a więc od czasów narodzin. W kolejnych rozdziałach możemy śledzić etapy dojrzewania ideowego bohatera oraz jego politycznej aktywności w szeregach PPS-u. Poszczególne fazy jego życia doskonale oddają tytuły poszczególnych rozdziałów $\mathrm{m}$. in: Szczenięce lata (rozdział 1), gdzie znajdziemy opis atmosfery domu rodzinnego A. Ciołkosza, z właściwymi mu tradycjami demokratycznymi i niepodległościowymi, Wolny harcerz (rozdział 3) traktujący o skautowej, harcerskiej działalności Ciołkosza, Brześ́ć (rozdział 6) - sugerujący epizod brzeski w życiorysie bohatera. Ciołkosz znalazł się bowiem w gronie polityków antysanacyjnej opozycji aresztowanych i osadzonych w twierdzy wojskowej w Brześciu nad Bugiem w 1930 r., a w dwa lata później skazanych w tzw. procesie brzeskim.

Z przywódcy tarnowskiej PPS Ciołkosz wyrósł z czasem na jednego z liderów krakowskiego ruchu socjalistycznego i stał się jednym z głównych działaczy PPS-owskiej centrali. Duża część książi poświęcona jest jego działalności po klęsce wrześniowej 1939 r., zaangażowaniu w emigracyjnych strukturach politycznych, czy na forum międzynarodowego ruchu socjalistycznego (Ciołkosz był na emigracji przedstawicielem polskich socjalistów w komitecie przygotowującym odbudowanie Międzynarodówki socjalistycznej). Profesor Friszke, świetnie orientujący się w tematyce powojennej emigracji politycznej, umiejętnie wplata losy swego bohatera w emigracyjną rzeczywistość naznaczoną sporami politycznymi oraz ideowymi tarciami.

Przy tym wszystkim otrzymujemy doskonałe kompendium wiedzy na temat PPS, wewnątrzpartyjnych sporów ideowych zarówno w kraju, jak i na emigracji. Na tle opisywanych w książce wydarzeń A. Ciołkosz jawi się jako postać stała w swoich poglądach. Społecznik, ideowiec, bezkompromisowy i niezłomny wszędzie tam, gdzie chodzi o interes własnej formacji politycznej i wierność własnym ideom. Jednym z dowodów owej bezkompromisowości okazała się sprawa brzeska. Mimo poniżania, 
ekstremalnych warunków panujących w twierdzy brzeskiej, Ciołkoszowi godnie udało się przetrwać ten trudny okres. Gdy niektórzy skazani politycy w procesie brzeskim udali się na emigrację (uczynili tak ludowcy, m.in. Wincenty Witos, Władysław Kiernik, Kazimierz Bagiński), chcąc uniknąć więzienia, Ciołkosz postanowił pozostać w kraju. Pragnął kontynuować pracę w partii, choć wiedział, że ta wkrótce zostanie przerwana z racji ciążącego na nim wyroku sądowego.

Ciołkosz był związany ze skrzydłem partyjnej lewicy PPS, ale zawsze zajmował pozycję przeciwną komunistom i komunizmowi. Prof. Friszke mocno akcentuje ten aspekt ideowego oblicza swego bohatera, tj. antykomunizm i kategoryczny sprzeciw wobec współpracy PPS z KPP. „Ciołkosz należał do nieprzejednanych wrogów ruchu komunistycznego i dawał temu niejednokrotnie wyraz w przemówieniach i publicystyce", stwierdza prof. Friszke ${ }^{1}$. W zakończeniu książki, oceniając dorobek pisarski w ostatnim etapie życia Ciołkosza, dodaje: „Był jednoznacznym antykomunistą i piórem walczył z komunizmem (...)"2. W ten sposób Autor spełnia główne założenie książki. Za postawą Ciołkosza kryje się przesłanie, że bycie socjalistą nie może być mylone z byciem komunistą, a socjalizm nie powinien być traktowany tożsamo z ideologią komunistyczną.

Zważywszy na objętość książki (510 stron!), zaskoczeniem może wydać się jej niekompletność. Losy bohatera, jak to już wcześniej zostało zasygnalizowane, doprowadzono nie jak w przypadku klasycznej biografii, do końca lat życia bohatera, ale do 1949 r. Informacja taka powinna być uwzględniona w tytule książki. Tymczasem dopiero po uważnym przeczytaniu części wstępnej można się zorientować, że mamy do czynienia z biografią niedokończoną, autor zaś zapowiada przygotowanie tomu II. Trzeba jednak przyznać, że jest to plan bardzo ambitny, świadczący o wnikliwości badacza, który życiorys swojego bohatera postanowił rozłożyć aż na dwa tomy. Tom pierwszy tworzy mimo wszystko pewną całość, jeśli uwzględnimy zamieszczone na 14 stronach Zakończenie. Rekompensuje ono niedosyt informacyjny, który może towarzyszyć czytelnikowi nastawionemu na zapoznanie się z kompletnym życiorysem bohatera. Znajdziemy tu

1 Zob.: A. Friszke, Adam Ciotkosz. Portret polskiego socjalisty, Warszawa 2011, s. 170.

${ }^{2}$ Ibidem, s. 498. 
podsumowanie ostatnich 28 lat życia bohatera. Zakończenie jest zarazem zapowiedzią tego, czego możemy spodziewać się w kontynuacji biografii Ciołkosza.

Rzetelność badawcza, która cechuje dokonania naukowe prof. Friszke, nie uchroniła go jednak od kilku drobnych uchybień. Pierwsza uwaga dotyczy braku konsekwencji w nazewnictwie partii komunistycznej na gruncie polskim. Znana wszystkim Komunistyczna Partia Robotnicza Polski, która ukonstytuowała się po 1918 r., zmieniła nazwę na Komunistyczna Partia Polski (KPP) dopiero w 1925 r. Tymczasem autor raz stosuje właściwą nazwę partii KPRP w odniesieniu do wydarzeń sprzed 1925 r., innym razem, opisując zdarzenia z tego samego okresu, pisze o KPP³. Na szczęście przypadek ten nie jest powielany.

Komentarza wymagałaby również nazwa „obóz koncentracyjny” stosowana w odniesieniu do Berezy Kartuskiej ${ }^{4}$. Wśród historyków nie ma zgodności co do zasadności stosowania takiego terminu i znacznie powszechniejszym w użyciu jest określenie o mniej pejoratywnym wydźwięku, „obóz odosobnienia”, które utrwaliły tytuły publikacji traktujących o Berezie Kartuskiej. Zwolennikami określenia „obóz koncentracyjny” są m.in. amerykański historyk, profesor uniwersytetu Yale, Timothy Snyder oraz Czesław Miłosz. Również A. Garlicki, badacz okresu II RP, biograf Józefa Piłsudskiego, w 2008 r. opublikował na łamach „Gazety Wyborczej” artykuł o znamiennym tytule Bereza, polski obóz koncentracyjny ${ }^{6}$. Mniej wytrawny czytelnik, a nawet historyk, który nie specjalizuje się w historii najnowszej i wcześniej nie spotkał się z taką nazwą, może czuć się nieco zdezorientowany. Stąd warto byłoby zaopa-

3 Ibidem, s. 41-42.

${ }^{4}$ Ibidem, s. 147-148.

5 W. Śleszyński, Obóz odosobnienia w Berezie Kartuskiej 1934-1939, Białystok 2003; P. Siekanowicz, Obóz odosobnienia w Berezie Kartuskiej 1934-39, Warszawa 1991; I. Polit, Miejsce odosobnienia w Berezie Kartuskiej, Toruń 2003.

${ }^{6}$ T. Snyder, The Reconstruction of Nations: Poland, Ukraine, Lithuania, Belarus, 1569-1999, London 2003, s. 167; C. Miłosz, The History of Polish Literature, London 1969, s. 383 (w obu publikacjach w odniesieniu do obozu w Berezie Kartuskiej autorzy posługują się terminem „concentration camp”, zob. też: A. Garlicki, Bereza, polski obóz koncentracyjny, „Gazeta Wyborcza”, 19-20 kwietnia 2008, nr 93.5703. 
trzyć uwagę na temat „obozu koncentracyjnego” w Berezie Kartuskiej w stosowny przypis.

Do mankamentów należy zaliczyć także brak bibliografii. Nota bibliograficzna nie dorównuje klasycznej i rzetelnie przygotowanej bibliografii, tym bardziej że w omawianej książce liczba wykorzystanych źródeł jest imponująca. Powyższe uwagi nie są jednak w stanie przysłonić atutów książki, którą cechuje duża wartość merytoryczna podparta rozległą bazą źródłową. Wszelkie tezy autora są podparte licznymi cytowaniami z różnych dokumentów i wspomnień. Dodatkowym walorem jest dość bogaty materiał ilustracyjny opatrzony w odpowiedni komentarz.

Lektury traktujące o polityce, działalności partyjnej i kwestiach ideowych często nie należą do lekkich i przyjemnych w czytaniu. Zasada ta jednak nie obowiązuje w przypadku recenzowanej książki, która jest napisana w sposób jasny i zrozumiały. Należy mieć także na względzie fakt, że jest to pierwsza tak solidnie opracowana biografia naukowa o Adamie Ciołkoszu, postaci nieco zapomnianej, a mogącej poszczycić się przecież interesującym życiorysem. 